\title{
Applicability of TOPMODEL in the mountainous catchments in the upper Nysa Kłodzka river basin (SW Poland)
}

\author{
Justyna Jeziorska ${ }^{1,2}$ (D) Tomasz Niedzielski ${ }^{1}$
}

Received: 14 September 2017 / Accepted: 9 February 2018/Published online: 9 March 2018

(C) The Author(s) 2018. This article is an open access publication

\begin{abstract}
River basins located in the Central Sudetes (SW Poland) demonstrate a high vulnerability to flooding. Four mountainous basins and the corresponding outlets have been chosen for modeling the streamflow dynamics using TOPMODEL, a physically based semi-distributed topohydrological model. The model has been calibrated using the Monte Carlo approach - with discharge, rainfall, and evapotranspiration data used to estimate the parameters. The overall performance of the model was judged by interpreting the efficiency measures. TOPMODEL was able to reproduce the main pattern of the hydrograph with acceptable accuracy for two of the investigated catchments. However, it failed to simulate the hydrological response in the remaining two catchments. The best performing data set obtained Nash-Sutcliffe efficiency of 0.78. This data set was chosen to conduct a detailed analysis aiming to estimate the optimal timespan of input data for which TOPMODEL performs best. The best fit was attained for the half-year time span. The model was validated and found to reveal good skills.
\end{abstract}

Keywords TOPMODEL $\cdot$ Hydrologic model $\cdot$ Discharge $\cdot$ Poland $\cdot$ Kłodzko land

\section{Introduction}

Better understanding of watershed dynamics is one of the key factors in solving water-related scientific and practical problems. This role becomes crucial for effective planning and management of water resources (Beven and Freer 2001a; Bastola et al. 2008) in areas endangered by extreme hydrological events. Key variables influencing the hydrological response of the catchment need to be estimated based on data recorded on gauges, and the limitations occur when data are poor or insufficient. Thus, the hydrological modeling of water cycle components is the essential tool which becomes necessary for extending hydrological data

Justyna Jeziorska

jajezior@ncsu.edu

Tomasz Niedzielski

tomasz.niedzielski@uwr.edu.pl

1 Faculty of Earth Sciences and Environmental Management, Institute of Geography and Regional Development, University of Wrocław, Wrocław, Poland

2 Center for Geospatial Analytics, North Carolina State University, Raleigh, USA both in space and time (Bastola et al. 2008). Many researchers attempted to develop solutions that would model the complexity of processes and heterogeneity of factors influencing the hydrological system dynamics. The availability of spatial characteristics of the catchment that rose with the advent of geographic information systems (GIS) shifted the research interests from the traditional lumped models towards more complicated, distributed ones. The advantage of the latter is the possibility of having a spatial pattern of the modeling outputs, such as soil moisture or saturation zone extent (Sun and Deng 2004). One of the semi-distributed and physically based conceptual models is the TOPography-based hydrological MODEL, known also as TOPMODEL (Beven and Kirkby 1979; Beven et al. 1995; Beven and Freer 2001a). It combines the advantages of two above-mentioned approaches. The number of parameters is reduced, but they maintain their physical interpretation. Simplified model structure diminishes the data requirements. Thus, this conceptual model integrates the ability to simulate the spatial distribution of its results at any time step (Choi and Beven 2007) with the computational efficiency that allows multiple simulations (Peters et al. 2003). These features 
contribute to the model popularity and successful applications in numerous studies. Furthermore, recent increase of the TOPMODEL application is caused by access to more detailed data describing the watershed characteristics.

According to Beven et al. (1995), the TOPMODEL concept should not be considered as a hydrologic modeling package, but rather as a set of conceptual tools that can describe the catchment behavior. Hence, since its introduction in 1979 (Beven and Kirkby 1979), many versions have been developed and numerous studies have applied the TOPMODEL approach to a wide range of hydrologyrelated topics. The research problems investigated with the use of TOPMODEL include: flood frequency analysis (Beven 1986; Cameron et al. 1999), scaling theory in hydrology (Wood et al. 1988), examination of the influence of the digital elevation model (DEM) resolution on the simulation results (Brasington and Richards 1998), analysis of climate change scenarios (Romanowicz 2007), water table estimation (Merot et al. 1995; Moore and Thompson 1996; Lamb et al. 1997), testing the applicability to water quality problems (Wolock et al. 1990; Robson et al. 1992), and uncertainty analysis (Freer et al. 1996; Choi and Beven 2007; Bastola et al. 2008; Fisher and Beven 1996).

Although the initial TOPMODEL applications concentrated on examining the catchment dynamics in the humid temperate climate zone in the UK (Beven and Kirkby 1979; Beven et al. 1984; Quinn and Beven 1993), in the eastern USA (Beven and Wood 1983; Hornberger et al. 1985), the capability of providing good simulation results have been proven in the variety of environments in basins all over the globe. TOPMODEL has been successfully used in temperate cold climate in Norway (Lamb et al. 1997). Furthermore, the model performance has been investigated in drier Mediterranean regimes (Durand et al. 1992; Piñol et al. 1997), and in the monsoon region of China (Chen and Wu 2012). The research was also carried out in the humid temperate (Cameron et al. 1999; Bárdossy 2007; Choi and Beven 2007; Furusho et al. 2014) and Mediterranean (Gallart et al. 2008) climate zones. TOPMODEL has also been successfully utilized in the tropical climate zone in French Guiana (Molicova et al. 1997) and within the same climate zone, but in its antipodes, in one of the most hydrologically responsive forested headwater catchments, in Maimai in New Zealand (Freer et al. 2003). Sigdel et al. (2011) applied the model to watersheds in the Bagmati River basin in Nepal. It is worth noting that many researchers focused their studies on the TOPMODEL applications in the Nepal region: Brasington and Richards (1998) applied the TOPMODEL to a small headwater catchment in the Nepal Middle Hills, Shrestha et al. (2007) investigated its performance in different physiographic regions of Nepal, and Bastola et al. (2008) conducted a comparative study of 26 catchments across the globe, including 4 basins in Nepal. The vast majority of the TOPMODEL applications concern small- or medium-sized catchments (up to several dozen of square kilometers); however, the model demonstrated good performance for: very small basins of 0.75 ha (Lamb et al. 1997) and of 1.57 ha (Molicova et al. 1997) as well as very large basins of over $25000 \mathrm{~km}^{2}$ (Sun and Deng 2004; Chen and Wu 2012). High attention has been paid to the TOPMODEL capability of rainfall-runoff modeling in the mountainous regimes. Holko and Lepistö (1997) applied the model to the Jalovecky Creek catchment in Western Tatra Mountains, Blazkova and Beven (1997) investigated mountain wetlands in the Czech-Moravian highlands, and the research area for Nourani and Mano (2007) was watershed located 800-2178 $\mathrm{m}$ a.s.l. in the western Iran.

The model has been successfully applied to several catchments in Central Europe. Emphasis should be placed on the above-mentioned research of Holko and Lepistö (1997), focusing on the mountainous watershed in Slovakia, and on the investigation by Bárdossy (2007) into 16 lowland catchments in the German part of the Rhine basin. Applications of TOPMODEL for Polish basins were rare and focused rather on selected episodes than on the entire hydrologic years (Table 1). Szalińska et al. (2014) applied the model in question to simulate discharges in selected gauges installed within upper Nysa Kłodzka and Soła basins, with the emphasis placed only on selected highflow events. Recent developments carried out in the Institute of Meteorology and Water Management-National Research Institute, Poland (Instytut Meteorologii i Gospodarki Wodnej-Państwowy Instytut Badawczy, IMGWPIB) include the Hydropath framework, the platform that includes TOPMODEL (Orczykowski and Tiukało 2016). More recently, Niedzielski and Miziński (2017) used TOPMODEL as one of ensemble members in the multimodel hydrologic ensemble prediction, within the HydroProg system implemented in Kłodzko Land.

Even though these studies demonstrated good modeling results, the TOPMODEL performance has never been tested in Poland in longer time perspectives than single highflow episodes. To fill this gap and fulfill a need of detailed analyses of the model in a variety of environments, postulated by Durand et al. (1992), in this study, TOPMODEL is applied to a few medium-sized catchments in the floodprone areas of the Sudety Mountains in SW Poland. Hence, the aim of the modeling experiment was to test the applicability of the TOPMODEL for the purpose of discharge simulation at the outlets of four contributing catchments of Nysa Kłodzka river (gauges: Bystrzyca Kłodzka, Kłodzko, Bardo) and the river of Biała Ladecka (gauge: Żelazno). In addition, the aim of the study is also to estimate the time span of data (discharge/rainfall/evapotranspiration) for 
Table 1 Applications of TOPMODEL for Polish basins and their sampling intervals

\begin{tabular}{|c|c|c|c|c|c|}
\hline Basin & River & Institution & References & Data & $\begin{array}{l}\text { Sampling } \\
\text { interval }\end{array}$ \\
\hline \multirow[t]{9}{*}{$\begin{array}{l}\text { Nysa } \\
\text { Kłodzka }\end{array}$} & Nysa Kłodzka (above Miedzylesie) & $\begin{array}{l}\text { IMGW- } \\
\text { PIB }\end{array}$ & Szalińska et al. (2014) & $\begin{array}{l}\text { Selected episodes from } 2010 \\
\text { to } 2012\end{array}$ & $1 \mathrm{~h}$ \\
\hline & $\begin{array}{l}\text { Nysa Kłodzka (above Bystrzyca } \\
\text { Kłodzka) }\end{array}$ & UWr & This paper & Hydrologic years 2009-2012 & $15 \mathrm{~min}$ \\
\hline & Nysa Kłodzka (above Kłodzka) & UWr & $\begin{array}{l}\text { Niedzielski and Miziński } \\
\text { (2017) }\end{array}$ & $\begin{array}{l}\text { Selected episodes from } 2014 \\
\text { to } 2015\end{array}$ & $15 \min$ \\
\hline & Nysa Klodzka (above Kłodzka) & UWr & This paper & Hydrologic years 2009-2012 & $15 \min$ \\
\hline & Nysa Kłodzka (above Bardo) & UWr & This paper & Hydrologic years 2009-2012 & $15 \min$ \\
\hline & Bystrzyca (outlet unknown) & $\begin{array}{l}\text { IMGW- } \\
\text { PIB }\end{array}$ & Szalińska et al. (2014) & $\begin{array}{l}\text { Selected episodes from } 2010 \\
\text { to } 2012\end{array}$ & $1 \mathrm{~h}$ \\
\hline & Biała Lądecka (outlet unknown) & $\begin{array}{l}\text { IMGW- } \\
\text { PIB }\end{array}$ & Szalińska et al. (2014) & $\begin{array}{l}\text { Selected episodes from } 2010 \\
\text { to } 2012\end{array}$ & $1 \mathrm{~h}$ \\
\hline & Biała Lądecka (above Żelazno) & UWr & This paper & Hydrologic years 2009-2012 & $15 \min$ \\
\hline & $\begin{array}{l}\text { Bystrzyca Dusznicka (above } \\
\text { Szalejów Dolny) }\end{array}$ & $\begin{array}{l}\text { IMGW- } \\
\text { PIB }\end{array}$ & Szalińska et al. (2014) & $\begin{array}{l}\text { Selected episodes from } 2010 \\
\text { to } 2012\end{array}$ & $1 \mathrm{~h}$ \\
\hline \multirow[t]{5}{*}{ Sola } & Sola (above Rajcza) & $\begin{array}{l}\text { IMGW- } \\
\text { PIB }\end{array}$ & Szalińska et al. (2014) & $\begin{array}{l}\text { Selected episodes from } 2010 \\
\text { to } 2012\end{array}$ & $1 \mathrm{~h}$ \\
\hline & Woda Ujsolska (outlet unknown) & $\begin{array}{l}\text { IMGW- } \\
\text { PIB }\end{array}$ & Szalińska et al. (2014) & $\begin{array}{l}\text { Selected episodes from } 2010 \\
\text { to } 2012\end{array}$ & $1 \mathrm{~h}$ \\
\hline & Zabniczanka (above Żabnica) & $\begin{array}{l}\text { IMGW- } \\
\text { PIB }\end{array}$ & Szalińska et al. (2014) & $\begin{array}{l}\text { Selected episodes from } 2010 \\
\text { to } 2012\end{array}$ & $1 \mathrm{~h}$ \\
\hline & Bystra (outlet unknown) & $\begin{array}{l}\text { IMGW- } \\
\text { PIB }\end{array}$ & Szalińska et al. (2014) & $\begin{array}{l}\text { Selected episodes from } 2010 \\
\text { to } 2012\end{array}$ & $1 \mathrm{~h}$ \\
\hline & Koszarawa (outlet unknown) & $\begin{array}{l}\text { IMGW- } \\
\text { PIB }\end{array}$ & Szalińska et al. (2014) & $\begin{array}{l}\text { Selected episodes from } 2010 \\
\text { to } 2012\end{array}$ & $1 \mathrm{~h}$ \\
\hline Kamienna & Kamieinna (above Jakuszyce) & $\begin{array}{l}\text { IMGW- } \\
\text { PIB }\end{array}$ & $\begin{array}{l}\text { Orczykowski and Tiukało } \\
\text { (2016) }\end{array}$ & Unknown choice of data span & $1 \mathrm{~h}$ \\
\hline
\end{tabular}

$I M G W-P I B$ Instyhit Mereorologii i Gospodarki Wodnej-Panstwowy Instytut Badawczy (Institute of Meteorology and Water ManagementNational Research Institute), $U W r$ Univtersytet Wroclawski (University of Wroclaw)

which the TOPMODEL performance is optimal. Therefore, the novelty of the work presented in this paper is twofold: (1) it presents new results on discharge modelling in the upper Nysa Kłodzka river basin in time scales of a few hydrologic years, hence not only for selected high-flow episodes; (2) it shows first attempts to relate modelling skills with time span of input data.

The paper is organized as follows: the next section presents a simplified description of the model (its concept and features), based on the extended explanations of TOPMODEL theory given by Beven and Wood (1983) and Beven (1986). The second section also contains overview of methods used for the model assessment. The study area is presented in the third section, followed by the fourth section that focuses on description of data used in the research. The results of land surface parameterization, model calibration, sensitivity analysis, and validation of the TOPMODEL for four contributing basins located within the upper Nysa Kłodzka basin (SW Poland) are included in the fifth section. They are concluded in the last section, which also offers an overview of potential future research activities.

\section{Methods}

\section{Concept of TOPMODEL}

The idea that runoff is primarily a result of overland flow generated by rainfall when infiltration capacity of the soil is exceeded is known as Hortonian theory of infiltration excess overland flow. However, in recent studies, it is commonly superseded by the contrary concept that emphasizes the significance of saturation-excess overland flow and subsurface runoff generation. On the contrary to the Hortonian concept, stating that the occurrence of surface overland flow is possible when the soil is not fully saturated, the saturated-excess overland flow theory assumes that the overland flow is generated when the soil is fully saturated to the surface or if subsurface flow returns to the surface in saturated areas (Nourani et al. 2011). Among different applications of this concept in hydrological modeling, one of the most widely used is TOPMODEL (Beven and Kirkby 1979; Beven 1997; Beven and Freer 
2001a). The predominant factors influencing the discharge generation in the model are topography of the basin and soil characteristics (Franchini et al. 1996). The topography is quantitatively expressed by the topographic index (also known as Topographic Wetness Index, TWI). Its value is computed from the basin topography using the following expression:

$\mathrm{TWI}_{i}=\ln \frac{a_{i}}{\tan \beta_{i}}$,

where $a_{i}$ is the upslope contributing area of $i$ th basin and $\tan \beta_{i}$ is slope of the ground surface of this basin. Upslope contributing area (Fig. 1) represents the area that can potentially produce runoff to the location of interest, i.e., to the outlet from the contributing basin (Erskine et al. 2006). In the raster representation of the terrain, it should be replaced by the upslope drainage area per unit of contour length (Moore and Wilson 1992; Moore and Burch 1986; Desmet and Govers 1996), which is equivalent to DEM grid cell size (Mitasova et al. 1996). Areas associated with high TWI values tend to saturate first and will, therefore, constitute potential subsurface or surface contributing areas (Gumindoga 2010; Beven 1997).

TWI refers to variable source area concept of runoff generation (Hewlett and Hibbert 1967) and is based on the following three simplifying assumptions regarding the
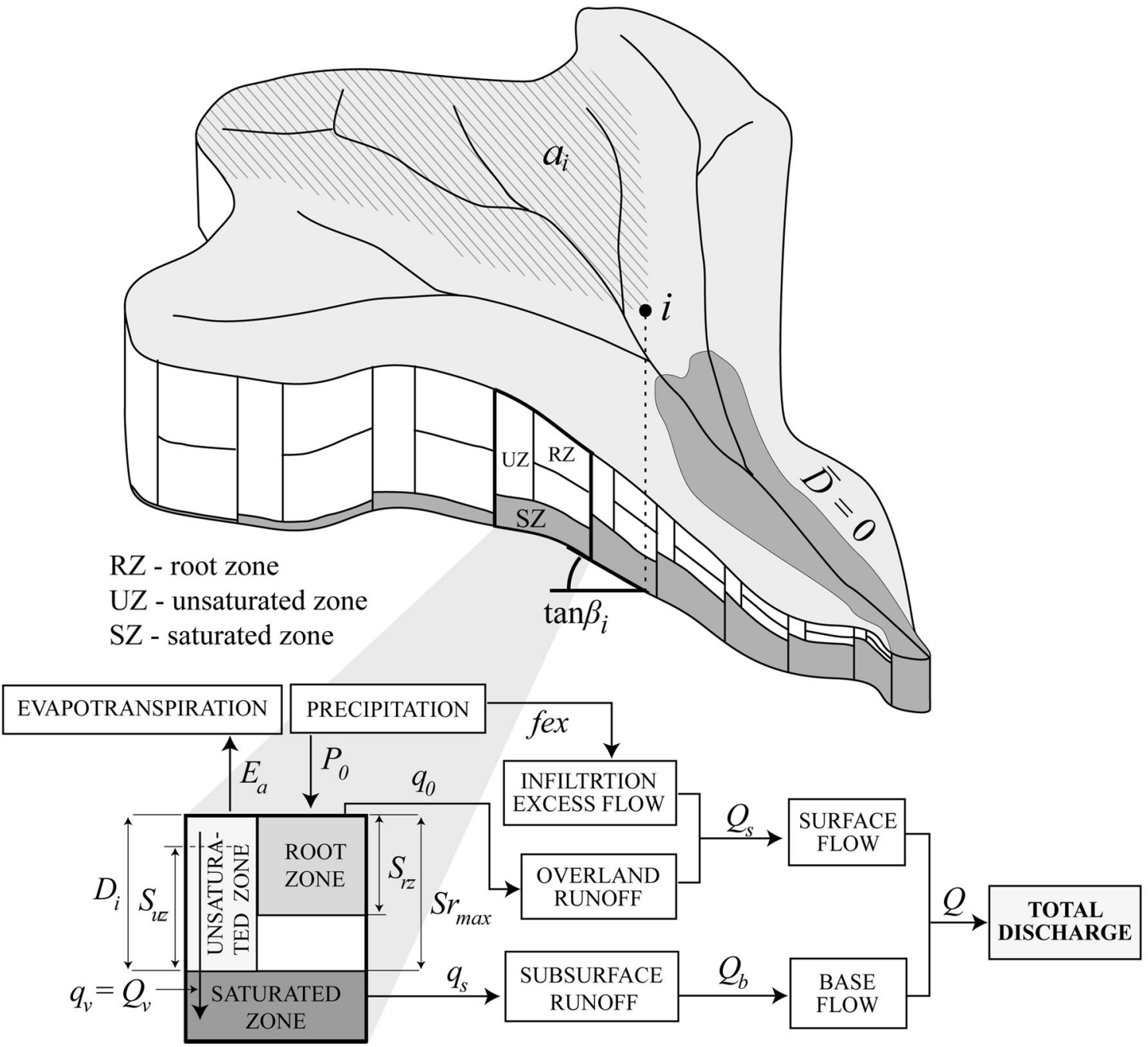

$Q_{v}$ - total flux, $\mathrm{q}_{\mathrm{v}}$ - the flux of water entering the water table locally (per unit area), $A_{i}$ - area associated with topographic index class, $E_{a}-$ actual evapotranspiration, $S r_{\max }-$ maximum root zone deficit, $S_{r z}$ - root zone deficit, $S_{v z}$ - local water storage in the unsaturated zone, $q_{0}$ - overland runoff, $P_{0}$ - precipitation per unit width, fex - infiltration excess flow, $Q_{s}$ - surface flow, $Q_{b}$ - base flow, $\mathrm{q}_{\mathrm{s}} \mathrm{z}$ - subsurface saturated zone flux, $\mathrm{Q}$ - total discharge

Fig. 1 Basic concept of TOPMODEL scheme. Based and combined from schemes by Nourani et al. (2011); Franchini et al. (1996); Gumindoga (2010) and Fisher and Beven (1996) 
hydrologic system (Nourani et al. 2011; Gumindoga 2010; Brasington and Richards 1998; Beven et al. 1995; Holko and Lepistö 1997):

- dynamics of the saturated zone can be approximated by successive steady-state representations;

- hydraulic gradient of the saturated zone can be approximated by the local surface topographic slope $\left(\tan \beta_{i}\right.$ ), and thus, the groundwater table and saturated flow are parallel to the local surface slope;

- distribution of downslope transmissivity with depth is an exponential function of storage deficit or depth to the water table.

This approach implies that all points with the same value of TWI respond in the same way (Fisher and Beven 1996). Calculations need to be performed only for representative values of the index, what greatly simplifies the procedure and reduces the computational cost while maintaining the capability of the identification of water table levels and soil moisture within the catchment (Chairat and Delleur 1993; Fisher and Beven 1996). The results may be mapped back into space using knowledge of the pattern of TWI derived from a topographic analysis (Beven 1997).

Sigdel et al. (2011) pointed out that the above assumptions may be valid for small and medium catchments, with shallow soils and moderate topography, which do not experience excessively long dry periods. The quasi-steadystate dynamics concept has been criticized (Barling et al. 1994; Beven 1997; Peters et al. 2003), and it cannot be always safely accepted (Beven 1997).

According to the TOPMODEL concept, there are two main factors that account for runoff generation, namely the catchment topography and the transmissivity that diminishes with depth (Beven and Kirkby 1979). A soil column in TOPMODEL is defined as a set of three stores: root zone, unsaturated zone, and saturated zone. They behave like three interdependent repositories (Fig. 1). The detailed explanation of physical processes taken into account with TOPMODEL calculations can be found in Peters et al. (2003), Taschner (2003), Sun and Deng (2004) and Sigdel et al. (2011).

The extended interpretation of the TOPMODEL theory is given by Beven and Wood (1983) and Beven (1986).

\section{Model performance measures}

Assessment of the efficiency of the hydrological model is necessary not only for the estimation of its ability to reproduce catchment behavior, but also for modifying model structure. Apart from the subjective visual inspection of the simulated and observed hydrographs, there are numerous statistical measures which can be used for hydrological model assessment (Krause et al. 2005). In this study, two model performance measures have been chosen: root-mean-square error (RMSE) and Nash-Sutcliffe efficiency (NSE). The latter was created specifically to assess hydrological models (Nash and Sutcliffe 1970) and can be calculated using the formula:

$\mathrm{NSE}=1-\frac{\sum_{t=1}^{N}\left(\mathrm{Qobs}_{t}-\mathrm{Qsim}_{t}\right)^{2}}{\sum_{t=1}^{N}\left(\mathrm{Qobs}_{t}-\overline{\mathrm{Qobs}}_{t}\right)^{2}}$,

where Qobs $_{t}$ is observed discharge, Qsim ${ }_{t}$ is simulated discharge at time step $t$, and $N$ is number of observations/ simulations. Although its value has been questioned (Criss and Winston 2008), it is still most widely used criterion for evaluating TOPMODEL performance (Beven and Binley 1992). The main critic relates to its sensitivity to extreme values and, since the hydrological data often contain outliers, the measure can be misleading. Values of NSE vary from $-\propto$ (strong misfit) to 1 (perfect fit), and the situation $\mathrm{NSE}=0$ occurs when model predictive skills are similar to performance of extrapolated mean of observations. According to Moriasi et al. (2007), there are several classifications of NSE and the corresponding interpretations, with a range of NSE intervals to describe a satisfactory model performance. Since the intervals vary significantly, NSE values greater than 0.6 are hereinafter assumed to describe a satisfactory fit (Beven and Freer 2001b).

\section{Study area}

The TOPMODEL performance was investigated using data from four gauges located in the Sudety Mountains in upper Nysa Kłodzka basin (SW Poland and the border region of Czech Republic). The following reasons led to the choice of the study area.

- The present research is associated with the HydroProg system (Niedzielski et al. 2014) in which TOPMODEL is used for predicting river stages in real time.

- Rainfall and water level data sets are available, and the access to date is courtesy of the authorities of Kłodzko County, the owner of the Local System for Flood Monitoring (Lokalny System Osłony Przeciwpowodziowej, LSOP).

- TOPMODEL has not been applied in the upper Nysa Kłodzka basin so far.

- TOPMODEL has been already shown to work well in small mountainous catchments in different parts of the world (e.g. Bastola et al. 2008; Cameron et al. 1999).

To investigate the performance of the model in different conditions, four gauges and the associated contributing basins were delimited (Bardo, Kłodzko, Bystrzyca Kłodzka, and Żelazno). The main features of the watersheds are presented in Fig. 2 and listed in Table 2. 
Fig. 2 Investigated watersheds and precipitation stations

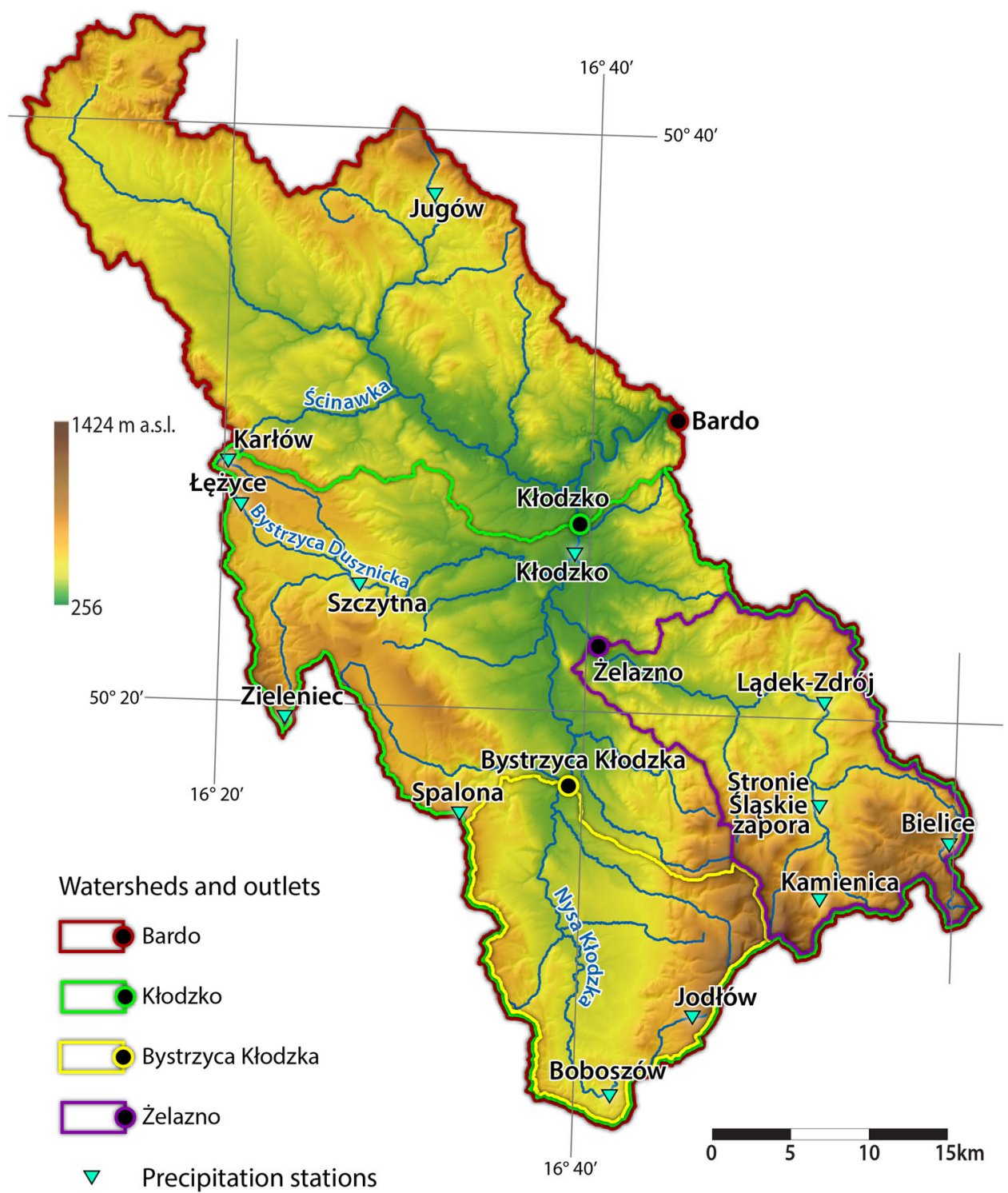

Table 2 Main characteristics of investigated watersheds

\begin{tabular}{lllll}
\hline Catchment outlet (gauge) & Bardo & Klodzko & Zelazno & Bygtrzyca Klodzka \\
\hline Altitude (m a.s.l.) & 259 & 285 & 341 & 319 \\
Area $\left(\mathrm{km}^{2}\right)$ & 1744.1 & 1079.31 & 259.985 & 302.94 \\
Mean altitude (m a.s.l.) & 534.79 & 567.45 & 576.53 & 648.06 \\
Elevation difference within the catchment (m) & 1165 & 1139 & 1024 & 1106 \\
Mean slope (\%) & 8.09 & 8.24 & 7.45 & 11.17 \\
Flow distance from source $(\mathrm{km})$ & 78 & 58 & 47 & 36 \\
Mean TWI & 7.37 & 6.91 & 6.81 & 6.34 \\
River & Nysa Kłodzka & Nysa Kłodzka & Biała Lądecka & Nysa Kłodzka \\
Mean observed flow $\left(\mathrm{m}^{3} / \mathrm{s}\right)$ & $19.19^{\text {a }}$ & $13.31^{\text {a }}$ & $4.8^{\text {a }}$ & $4.29^{\text {a }}$
\end{tabular}

åBased on: http://bip.umwd.pl/fileadmin/user_upload/woda_i_melioracja/Program_Malej_Retencji_Wodnej_tekst_jednolity_10_2006.pdf 
The Sudety Mountains are a medium-high mountain range spread along the Polish-Czech boundary in Central Europe. A maximum elevation of the mountains is equal to $1603 \mathrm{~m}$ a.s.l. Sudety Mountains are an example of faultblock mountains which are characterized by fault-generated mountain fronts and structural basins attributed to upand downfaulting in the late Cenozoic (Migon and Placek 2014). Diverse tectonic structure is additionally enhanced by the lithological complexity. Highly complex and diversified landscape is a result of the mosaic of underlying geology and its polygenetic origin (Wieczorek and Migoń 2014). The structure has also significant impact on extreme events: meteorological, hydrological, and geomorphological ones (Migon and skutki 2010). Large elevation differences strengthen foehn effects and reinforce orographic rainfall that can lead to flood wave formation in mountainous steep-slope streams (Migon and skutki 2010).

The main river of the study area is Nysa Kłodzka, the left tributary of the Odra River. It is characterized by rapid water supplies in the spring and summer as a result of concentric arrangement of numerous tributaries, which are mostly mountain streams. Table 2 juxtaposes main characteristics of the studied basins, along with mean discharges measured at four outlets under study. Three of the investigated basins have outlet located along Nysa Kłodzka. The largest one, with the area of $1744 \mathrm{~km}^{2}$, is the contributing basin above the gauge in Bardo. Further southward, $16 \mathrm{~km}$ upstream, located is the Kłodzko gauge which closes the second biggest of the investigated basins. The smallest one, still located along Nysa Kłodzka, is the basin above the gauge in Bystrzyca Kłodzka, with the area of nearly $260 \mathrm{~km}^{2}$. However, the Żelazno gauge is located along Biała Ladecka which is the longest right tributary of Nysa Kłodzka in the study area. The contributing basin above Żelazno is a subcatchment of Bardo and Kłodzko basins.

The study area belongs almost entirely to Poland; only the NW parts of the Bardo catchment belong to Czech Republic. That division makes the data related to geographical characteristics of the entire investigated area (i.e., soil cover and land use) not compatible due to different national classification criteria. Thus, the detailed statistical data, that can be assumed as representative for the study area, are available for Kłodzko County which is the administrational unit covering $84.17 \%$ of the area of interest.

The topography of the research area, i.e., Kłodzko Valley and the upper Nysa Kłodzka basin surrounded by mountain ranges, is responsible for its distinct microclimate. Although the investigated catchments, as the entire Sudety Mountains, are located in the cool temperate climate zone with marked maritime influences (Schmuck
1969), diversity between the main climate components is noticeable. Average annual air temperature calculated for the entire area of Kłodzko County is $6.3{ }^{\circ} \mathrm{C}$ (Geographic Characteristic of Counties 2004). Allowing for the temperature drop with altitude, it is lower than $1{ }^{\circ} \mathrm{C}$ at the summits (Waroszewski et al. 2013). In contrast, in Kłodzko Valley (most of Bystrzyca Kłodzka and Żelazno subcatchments), the annual average temperature rises to approximately $7.4{ }^{\circ} \mathrm{C}$ (Schmuck 1969). The altitude influence is also clearly seen in the annual precipitation sums, which vary from $590 \mathrm{~mm}$ in the lower parts of Kłodzko Valley to about $1500 \mathrm{~mm}$ at the summits (Godek et al. 2015). The mean annual precipitation rate calculated for the entire county is $803 \mathrm{~mm}$ (Geographic Characteristic of Counties 2004), and at the altitude of $800 \mathrm{~m}$ a.s.l., annual rainfall varies between 800 and $1000 \mathrm{~mm}$ (Latocha and Migoń 2006). While the storms with rainfall intensity 20-50 mm/day are not considered to be abnormal (Piasecki 1996), catastrophic rainfall episodes with daily precipitation exceeding $50 \mathrm{~mm}$ are observed rarely-a few times per decade (Pawlik et al. 2013). Snow cover is present in the Kłodzko station for average of 63 days (Bednorz 2011) with the first occurrence in November and last in April.

In the river valleys of Nysa Kłodzka, Biała Ladecka, Ścinawka, and lower reach of Bystrzyca Dusznicka, the groundwater level does not exceed $2 \mathrm{~m}$ (Geographic Characteristic of Counties 2004). It changes with the distance from the river, and $2-6 \mathrm{~km}$ from the channel, it deepens to $10 \mathrm{~m}$. The lowest water levels occur within the mountain massifs and can reach depth of several tens of meters.

The soil pattern is homogenous in the studied catchments. The soil types of the region are mainly Brown Earths and Podzoles. The river valleys are covered with Fluvisoles (Geographic Characteristic of Counties 2004).

\section{Data}

The data which become inputs to TOPMODEL can be divided into two groups, i.e., hydrometeorological time series (temporal variability) and terrain characteristics (spatial variability). The next two subsections correspond to this classification. For the purpose of the experiment, 4 consecutive hydrologic years have been selected, abbreviated hereinafter as HYs (note that in Poland hydrologic year begins on 1 November and finishes on 31 October). These HYs are: 2009, 2010, 2011, and 2012. Only four contributing basins which are mentioned and characterized above are the focus of the study. 


\section{Hydrometeorological time series}

Time series of discharge, rainfall, and potential evapotranspiration are needed to calibrate TOPMODEL. They all should be calculated in $\mathrm{m} / \mathrm{m}^{2}$ per time step. The observed river flow and precipitation data, sampled every $15 \mathrm{~min}$, are obtained from the above-mentioned Local System for Flood Monitoring, known also as LSOP, courtesy of Kłodzko County. However, potential evapotranspiration is modelled empirically, and the same 15-min time step is kept.

Since LSOP observes only water level, and thus, no discharge is measured, there is a need to use rating curves to calculate discharge time series. This has been done using the tabulated rating curves for four gauges under study, obtained courtesy of IMGW-PIB. The validity periods of the rating curves were the following: for Bystrzyca Kłodzka (06/11/2012), for Kłodzko (01/02/2013), for Bardo (30/01/2013), and for Żelazno (09/12/2012). For a few model calibration exercises, the curves were slightly newer, but the adequacy of their performance in calculating discharges from LSOP-based water levels was confirmed by the comparison with discharges measured by IMGWPIB. The tabulated rating curves, after applying the squareroot transformation to the discharge data, have been approximated with high-order polynomials which have been fitted using the least-squares method. Attention has been paid to the uniqueness of the model solution, specifically for low flows. The models have used to compute discharge time series, expressed in $\mathrm{m}^{3} / \mathrm{s}$, for four sites under scrutiny, and sampling every $15 \mathrm{~min}$ have been inherited from river stages. Since discharge data should be expressed in $\mathrm{m} / \mathrm{m}^{2}$ per time step, for each gauge, so calculated discharge was multiplied by $15 \times 60(15 \mathrm{~min}$ between consecutive discharge data times $60 \mathrm{~s}$ in a minute) and divided it by basin area (expressed in $\mathrm{m}^{2}$ ).

Rainfall is measured in LSOP at 13 automatic weather stations, and hourly precipitation rate is recorded every $15 \mathrm{~min}$. The data have been recalculated to fit the 15-min time step, and millimeters of rainfall have been converted to $\mathrm{m} / \mathrm{m}^{2}$ per time step. Since no continuous information on precipitation field is provided, the Thyssen polygons have been applied to relate rainfall to a given contributing basin.

Potential evapotranspiration has been computed empirically, i.e., an averaged time series have been constructed. It is assumed to be valid for every year. In our exercise, the evapotranspiration data set is a combination (sum) of: the daily-averaged potential evapotranspiration data for the entire year (computed for each day of year as a mean potential evapotranspiration on the corresponding days in many years) and the diurnal harmonic variation computed on the basis of the true sunrise and sunset times.
Due to the fact that the daily evapotranspiration data are not available for Kłodzko Land, the daily potential evapotranspiration data for the nearest German site of Goerlitz have been utilized, they were computed using the TurcWendling method in frame of the NEYMO project. Since Goerlitz is located approximately $140 \mathrm{~km}$ from the center of Kłodzko Land, a scaling approach is proposed to account for change in evapotranspiration between Goerlitz and the considered sites in Kłodzko Land. Thus, the dailyaveraged evapotranspiration data for Goerlitz have been multiplied by a constant number which was a ratio of: (1) mean annual potential evapotranspiration between 1966 and 1995 in a single site in Kłodzko Land $(499 \mathrm{~mm}$ for Bystrzyca Kłodzka as well as 516 mm for Kłodzko, Bardo, and Żelazno); and (2) mean annual potential evapotranspiration between 1966 and 1995 in Zgorzelec which is equal to $570 \mathrm{~mm}$ (Zgorzelec is a Polish town that forms an entity with German town of Goerlitz). The resulting ratios, computed using values published by Drabiński et al. (2006), led to the calculation of daily-averaged potential evapotranspiration data for basins above gauges in Bystrzyca Kłodzka, Kłodzko, Bardo and Żelazno.

Diurnal harmonic variation was simulated on a basis of true sunrise and sunset times. It was assumed that evapotranspiration is equal to zero in the night and starts growing non-linearly after the sunrise, which reaches the daily maximum and declines to zero at sunset. In this paper, the day segment was modelled with a sinusoid and replicated many times to reveal the same length as the above-mentioned daily evapotranspiration data. The similar, but not entirely identical approach, was applied by Liu et al. (2005). In our exercise, the mean value of the diurnal components was subtracted, and such a procedure prevented extra evapotranspiration values to occur when integration over time was performed.

Subsequently, the data-based daily-averaged potential evapotranspiration data were added to the mean-corrected diurnal evapotranspiration component, leading to the ultimate estimate of potential evapotranspiration.

A note should be given here on why the above-mentioned approach for estimating potential evapotranspiration has been selected. The TOPMODEL configured as described in this paper is used in the experimental multimodel hydrologic ensemble prediction system, known as HydroProg (Niedzielski et al. 2014). It is, therefore, natural that for reference to the system itself and to the previously published work on the use of TOPMODEL in HydroProg (Niedzielski and Miziński 2017), the same settings of the model should be kept to allow comparisons. However, it is likely that the empirical method for estimating averaged time series which is assumed to be valid for every year may become one of the sources of calibration errors. 


\section{Terrain characteristics}

Topography of the investigated watersheds, as a major factor influencing the TOPMODEL performance, was, in this study, a subject of scrutiny. Digital Elevation Model for the watersheds was interpolated to $25 \mathrm{~m}$ grid based on LiDAR data. The grid size was this is a compromise between using a lower resolution that causes a loss of information about hillslope flow pathways, and a high resolution that is influenced by noise (Nourani and Zanardo 2014). Based on the flow accumulation maps generated using GIS tools, the TWI value was assigned to each raster cell in the digital elevation models of the watersheds. The classification of the values into 16 classes (Blazkova and Beven 1997; Holländer et al. 2009) was performed to reduce the computation time, and thus, the calculations were carried out for the topographic index class instead of each individual value. Figure 3 shows the frequency and the spatial distribution of the TWI values. It is clearly seen that the highest values-which indicate potential subsurface or surface contributing areas (Beven 1997) - are associated with the bases of slopes and the stream valleys. These areas are characterized by large contributing areas and relatively flat slopes. The mean TWI for the watersheds varies from 6.34 for Bystrzyca Kłodzka catchment, through 6.81 and 6.91 for Żelazno and Kłodzko, respectively, to the highest mean value of 7.37 obtained for the Bardo catchment.

DEM was also used for the estimation of the delay function which represents the time for a particle of water to travel to the outlet. Based on the flow length map, each watershed was divided into five zones, grouping the similar values of the function. The simple matrix was prepared for the further computations, with the first column indicating average distance to the outlet and the second column representing relative cumulative area of each zone.

\section{Results}

\section{Parameter estimation}

Although the TOPMODEL assumptions require relatively small number of parameters that need to be estimated, the

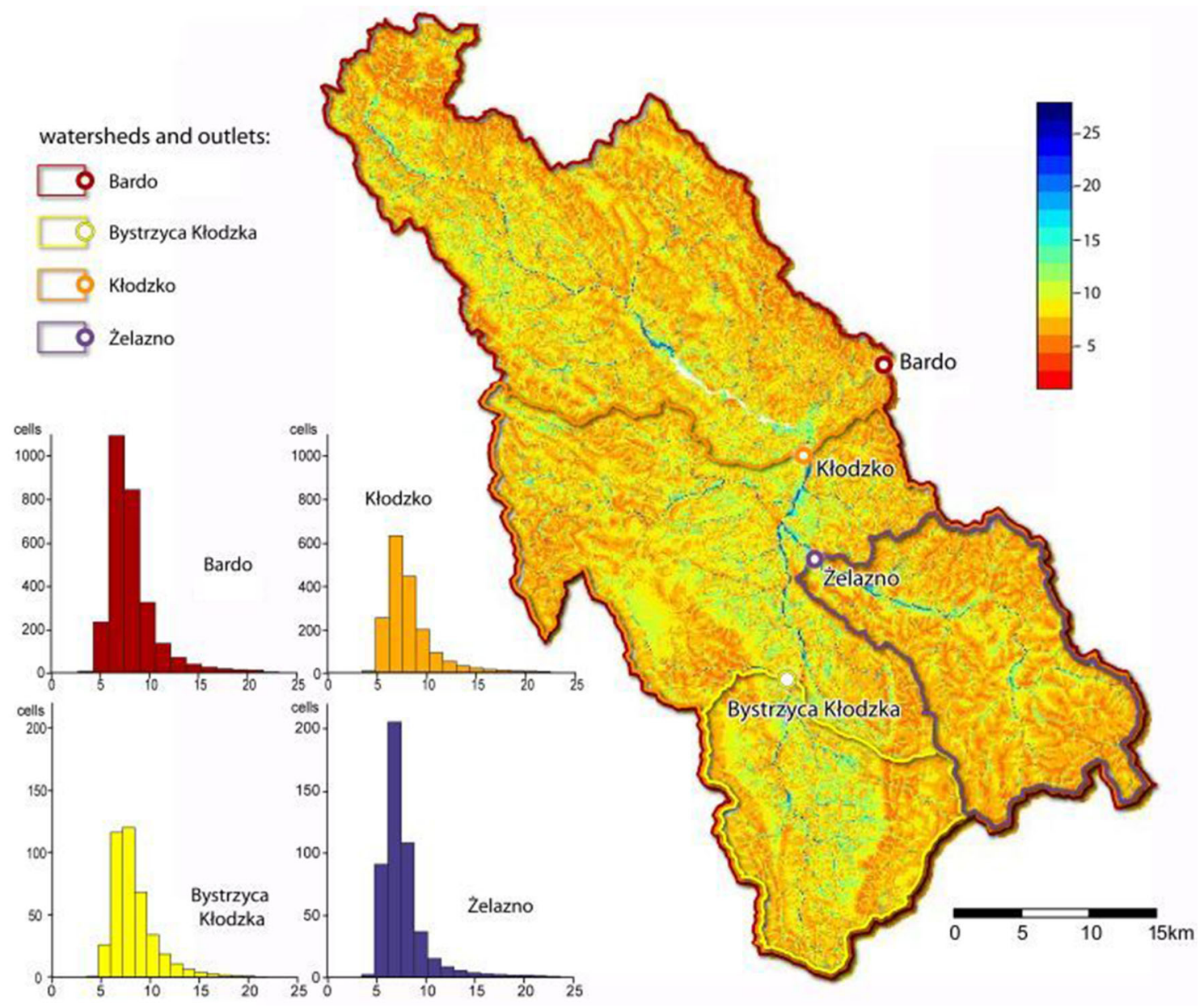

Fig. 3 TWI values and its distribution in investigated catchments 
difficulty of the calibration is caused by the uncertainty of the parameters (Kuczera and Mroczkowski 1998). In addition, as Beven and Freer (2001b) stress out, a diverse set of possible parameter values can produce similar modeling results.

The Monte Carlo procedure, that has been proven to be particularly useful for hydrological studies (Romanowicz and Beven 2003), was carried out to estimate a set of parameters that offer the best model performance. In this paper, the Monte Carlo approach is used in association with the uniform distribution, i.e., random sampling across the specified parameter range is performed, assuming the same probability of sampling each element. Table 3 shows the ranges applied for each parameter based on the previous studies and manual calibration. The ranges of the parameters were kept wider than the expected possible values for the catchment (Freer et al. 1996). To enhance the certainty, the number of simulations was set to 10,000. Further increase of this number did not improve the final result and required a more time-consuming computation. The procedure was carried out for all above-mentioned catchments, in each case study for the period of 1 hydrological year, and the data from HY 2010, HY 2011, and HY 2012 were taken as an input. Table 3 confirms the statement that constraining the perfect parameter set is not possible and the modeling needs to rely on the best performing, not necessary actual, values. In the experiment, three independent calibration exercises (HY 2010, HY 2011, and HY 2012) are carried out to show the level of variability of model parameters and its impact on model performance.

Each parameter is equally important during the Monte Carlo sampling, although the manual calibration showed that four of the parameters- $m, \operatorname{lnTe}, \mathrm{Sr}_{\max }$, and vch-are more meaningful, i.e., variation in their values influences the model performance and the shape of the simulated hydrograph most significantly. The highest sensitivity is associated with $m$ parameter, which represents the change in the saturate hydraulic conductivity with depth. Small values of $m$ imply the quick flow and insignificant subsurface runoff, while large values indicate that more rainfall can infiltrate the soil, and thus, less water reaches the outlet via surface route (Sigdel et al. 2011). For the investigated catchments, $m$ parameter range was kept wide, assuming that the well-vegetated, deep-seated catchments of the study area can be well characterized by the large values of $m$. The next highly sensitive parameter, $\operatorname{lnTe}$, influences directly the shape of hydrograph. The quick recession is associated with small values of the $\ln \mathrm{Te}$ parameter, while low values result in gradual fall of the hydrograph limb after the peak, as a result of increasing saturated transmissibility that may cause runoff delay. This parameter draws a special attention in this study, since the shape of the recession limb in the modelled hydrographs often did not resemble the observed ones. Constrained allowable range for this parameter was set to be between -2 and 1 , and its value for the most efficient runs varies from - 1.37 (Bystrzyca Kłodzka catchment, simulation for 2011) to 0.99 (Żelazno catchment, simulation for 2012). The third parameter that was found to be sensitive, although not as much as the previous ones, is the maximum root zone deficit $\mathrm{Sr}_{\max }$. The value of this parameter indicates the influence of evapotranspiration on the hydrological behavior of the catchment. Small root zone deficit (low $\mathrm{Sr}_{\max }$ value) allows less water to be stored in the root zone and hence available for evapotranspiration (Sigdel et al. 2011) what can lead to the increased runoff. An extended knowledge of the catchment vegetation is necessary for the $\mathrm{Sr}_{\max }$ calculation. The difference of the water contents at field capacity and the permanent wilting point needs to be multiplied by the rooting depth of the soil (Beven and Freer 2001a). Due to the lack of such detailed data, $\mathrm{Sr}_{\max }$ parameter ranges were very wide $(0-3 \mathrm{~m})$. The best performing parameter sets for the simulations for different HY in the same catchment contained $\mathrm{Sr}_{\max }$ parameters with

Table 3 Parameter ranges applied for random sampling in the Monte Carlo procedure and their significance

\begin{tabular}{llll}
\hline Parameter & & Range & Significance \\
\hline qs0 & Initial subsurface flow per unit area $(\mathrm{m})$ & 0 to 0.00004 & Insensitive \\
$\mathrm{lnTe}$ & Log of the areal average of $T 0\left(\mathrm{~m}^{2} / \mathrm{h}\right)$ & -2 to 1 & More sensitive \\
$m$ & Model parameter controlling the rate of decline of transmissivity in the soil profile & 0 to 2 & Highly sensitive \\
$\mathrm{Sr} 0$ & Initial root zone storage deficit $(\mathrm{m})$ & 0 to 0.02 & Insensitive \\
$\mathrm{Sr}$ max & Maximum root zone storage deficit $(\mathrm{m})$ & 0 to 3 & Sensitive \\
$\mathrm{td}$ & Unsaturated zone time delay per unit storage deficit $(\mathrm{h} / \mathrm{m})$ & 0 to 3 & Less sensitive \\
$\mathrm{vr}$ & Channel flow inside catchment $(\mathrm{m} / \mathrm{h})$ & 800 to 1000 & Sensitive \\
$k 0$ & Surface hydraulic conductivity $(\mathrm{m} / \mathrm{h})$ & 0 to 0.01 & Less sensitive \\
$\mathrm{CD}$ & Capillary drive & 0 to 5 & Insensitive \\
\hline
\end{tabular}


various values, and the estimation of the right span was difficult. Constraining the ranges for the last highly sensitive parameter did not cause such problems, since channel flow velocity can be estimated by dividing the observed discharge by the cross-sectional area of the stream. The channel velocity varies along the stream, but for all the investigated catchments, the best performed parameter sets were generated when the each parameter range was set to $800-1000 \mathrm{~m} / \mathrm{s}$.

There final parameter values' ranges presented in Table 4 which yielded the best overall fit of the model when executed for entire hydrograph for a HY.

\section{Model performance}

The calibration of the model was performed on all four watersheds for HY 2010, HY 2011, and HY 2012. The rainfall, discharge, and evapotranspiration data were converted to 15 -min time steps, and the Monte Carlo procedure was performed to generate the best performing parameters set out of 10,000 individual sets. Table 4 shows the modeling results and the calibrated parameter values. Obtained efficiency statistics as well as the parameter ranges are not consistent for all catchments and all simulation periods. For all of the catchments, TOPMODEL achieved the best fit modeling the discharge in HY 2011. The topography, land use, soils, and other characteristics of terrain influencing the runoff generation were relatively steady, but model efficiency statistics varied between the modeling time periods, which proves that the model performance measures are strongly dependent on weather conditions.

The best performance of TOPMODEL was found for Bystrzyca Kłodzka catchment in HY 2011, with $\mathrm{NSE}=0.78$ and the correlation between observed and simulated discharge of 0.89 (Fig. 4). Slightly less skillful was TOPMODEL in Kłodzko catchment, with values of the above-mentioned statistics of 0.66 and 0.83 , respectively. The model performance expressed by NSE $>0.6$ is considered as satisfactory, also named as behavioral (Beven and Freer 2001b). For two remaining catchments, Bardo and Żelazno, TOPMODEL was unable to simulate the hydrograph with fair accuracy. In Bardo basin, the modelled discharge was, for each time period, less accurate as the mean of the observed data (NSE < 0). For Żelazno catchment, this situation occurred for the HY 2012 data, and the results for the remaining modeling periods, HY 2010 and HY 2011, were also not satisfactory, with $\mathrm{NSE}=0.31$ and 0.42 , respectively.

Based on the results of calibration using the yearly data, the watersheds were categorized into three categories: "good"-all obtained NSE $>0$, "acceptable"-all obtained NSE $\geq 0$, and "unacceptable" — some obtained NSE $<0$ (Blazkova et al. 2002). The third category, containing two watersheds-Żelazno and Bardo-was excluded from further analysis and the emphasis was put on finding the underlying causes of model bad performance in these basins.

Bardo is the biggest of the investigated catchments (Fig. 2) and includes the basin of the left Nysa Kłodzka river tributary-i.e., Ścinawka. Within this watershed, there is only one meteorological station with rain gauge. Hence, due to numerous local anomalies in the precipitation field in the study area (orographic precipitation, rain shadows), the precipitation measurements weighted by Thiessen polygons are imprecise representation of real spatial variability of rainfall. Both dense distribution of measurements in the mountainous areas and relatively small number of stations located on the plains and in the NW part of Bardo watershed lead to the difficulty in adjusting model parameters and, as result, in accurate simulating discharge. Żelazno is a watershed with the most diverse topography; hence, the local anomalies in precipitation occur more frequently and have greater impact on model misrepresentation of the spatial rain pattern. It is also considered that the soil properties in this forested watershed (forests compose over $63 \%$ of land use) can exhibit seasonal variability which is more significant than in remaining watersheds. Further investigation into the latter problem is needed, because Polish digital soil maps provide information about soil properties only for agricultural land (Drzewiecki et al. 2014), and thus, there are no data for forested areas.

For Bystrzyca Kłodzka and Kłodzko watersheds, TOPMODEL performed better in predicting discharge than the observed mean. The only exception is associated with Kłodzko watershed in HY 2010, for which the model predictions were exactly as accurate as the mean observed discharge $(\mathrm{NSE}=0.03)$. In the watershed where TOPMODEL performance was superior over the remaining basins, i.e., Bystrzyca Kłodzka, the model obtained the highest efficiency for HY 2011, what is consistent with other watersheds investigated in HY 2011. It may hypothesized that meteorological conditions in this HY differed significantly from the remaining calibration HYs, and the processes involved in these conditions can be better represented by the model. This may be confirmed by the analysis of rainfall and discharge patterns in Kłodzko station (Table 5).

The primary difference in the shapes of hydrographs for HYs 2010-2012 is the existence of a large mid-summer peak as a result of major storm event occurring on 24/07/ 2011. The peak was reconstructed well by the model-its underestimation by over $20 \%$ is acceptable taking into 


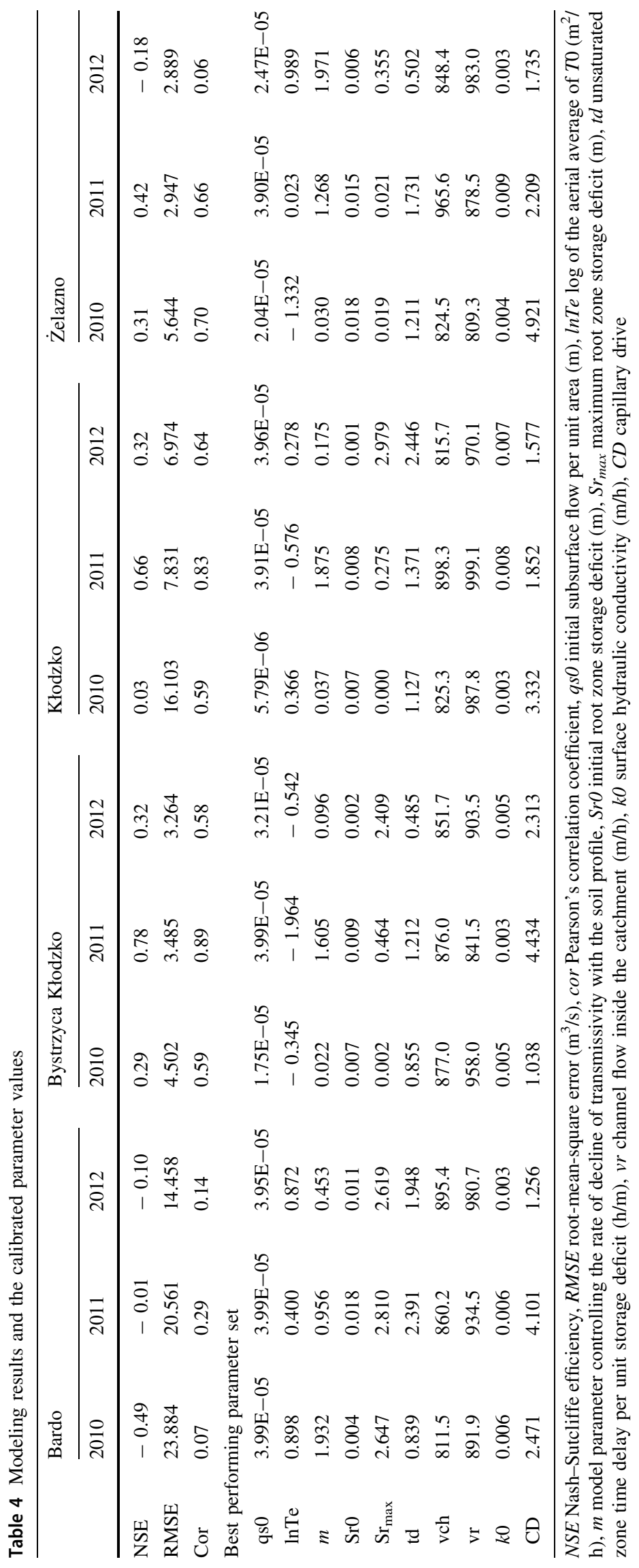



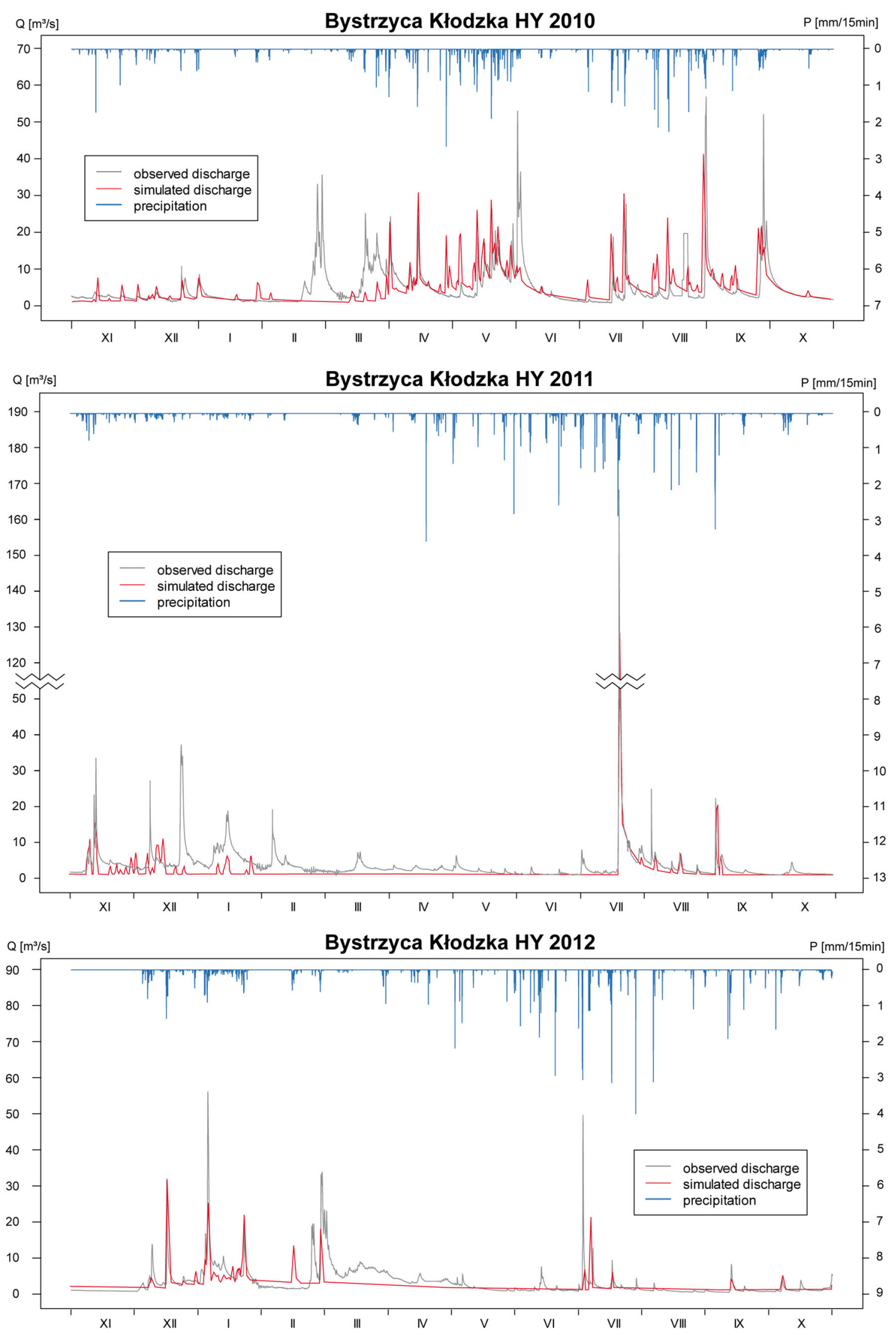

Fig. 4 TOPMODEL simulation results for the Bystrzyca Kłodzka watershed 
account the magnitude of the event. The well-fitted parts of the hydrograph include also recession curve after the main peak, and modelling such situations is perceived as one of the most problematic responses to be reconstructed by the TOPMODEL (Sigdel et al. 2011). The model was able to predict smaller peaks after the event and the estimation of the base flow also improved after the main peak. The biggest discrepancies between observed and simulated runoff occur in the winter season. This is due to the limitation of this simple version of TOPMODEL which does not account for the water accumulated in snow cover. Because the model uses the same parameters to estimate the discharge during the whole simulation period, its values need to be calibrated to produce the smallest overall prediction error, for different hydrological settings. In such a case, the model seems to provide superior fit to the large peaks rather than to other hydrological situations. The evaluation of model performance on a basis of NSE itself can be misleading due to the inclination of this measure to place emphasis on the larger errors, while the smaller ones tend to be neglected. The acceptable performance of the model during one extreme event contributes to good statistical performance for entire hydrograph and poor results in the representation of the base flow. Although this discrepancy occurs during long periods of simulation for low flows, its impact on the overall efficiency measure is rather small. The model parameters estimated with support of this criterion produce a hydrograph that recreates peaks with reasonable accuracy, but fails to match the observed hydrograph during low flows. In 2011, despite the high $0.78 \mathrm{NSE}$, the model underestimated the mean discharge by over $40 \%$, similar to the HY 2012 with much lower NSE of 0.29 .

The same pattern can be observed in Kłodzko catchment. In this case, the recession curve was not reproduced as accurately and the overall model performance is lower $(\mathrm{NSE}=0.66)$ than in Bystrzyca Kłodzka catchment (Fig. 5). The model does not provide a good representation of hydrograph during the winter season, when discharge is impacted by snow-melt and water can be stored in snow cover. Similar situation was detected also on other hydrographs for all the catchments, i.e., simulations for period December-April were found to be inaccurate. This leads to

Table 5 Rainfall and discharge patterns in Kłodzko station and the NSE values obtained in the simulations

\begin{tabular}{llll}
\hline & 2010 & 2011 & 2012 \\
\hline Mean observed discharge $\left(\mathrm{m}^{3} / \mathrm{s}\right)$ & 3.11 & 3.82 & 4.81 \\
Mean simulated discharge $\left(\mathrm{m}^{3} / \mathrm{s}\right)$ & 3.61 & 2.27 & 2.92 \\
NSE & 0.29 & 0.78 & 0.32 \\
Precipitation $(\mathrm{mm})$ & 748 & 758 & 836 \\
\hline
\end{tabular}

the conclusion that snow component should be included in the model structure to properly reconstruct the hydrological behavior of the investigated catchments in winter seasons. To confirm the impact of this misrepresentation of the hydrograph, the model was tested on the shorter periods and the following section contains the results of this simulations.

\section{Optimal time span for simulations}

The best performing watershed-Bystrzyca Kłodzka-was chosen to conduct a detailed analysis of the model ability to reproduce hydrological response during periods of different lengths. It was assumed, based on the shape of the simulated hydrograph for entire year in relation to the observed one, that the model performance during the winter season will exhibit the lowest accuracy expressed by the NSE. To determine the most optimal time span for the model simulations, the periods of 1 week, 2 weeks, 3 weeks, 1 month, 2 months, 3 months, and 6 months were taken into account. Table 6 shows the results for HY 2011, where a given time span (e.g., 1 week of data) was iteratively moved forward by 1 day (which corresponds to 96 observations) to rerun simulations and get a set of statistics. Figure 6 depicts the variability in achieved NSE values for 2-week, 1-month, and 6-month periods.

The overall performance of a model for particular time period was judged subjectively by comparing the efficiency measures obtained by each simulation independently. To shorten the time-consuming calculations, the number of simulations in the Monte Carlo procedure has been reduced from 10,000 to 1000 . It was impossible to find the timespan that would give satisfactory results for all hydrological settings, and this is clearly seen when analyzing winter seasons. The mean NSE, calculated for a window of a given length moved in a stepwise way through the entire year, is severely impacted by the low values representing the periods in winter season. Most sensitive to this effect, and thus producing dispersed values, were shorter periods-standard deviation of NSE for the 1-week period exceeds $2 \mathrm{~m}^{3} / \mathrm{s}$. The NSE of the best-fitted parameter set in all periods is very high, namely of $0.95-0.97$, but these values relate mostly to the time spans when the discharge rate is stable and this stability is expressed properly by the model. To avoid the positive bias, percentage of the parameter sets that can be considered behavioral (NSE > 0.6) and percentage of the parameter sets that perform better than the mean of observed values (NSE $>0$ ) have been calculated. The variability of the mean NSE among the investigated periods is high, but the ratio of behavioral parameter sets and especially parameter sets with NSE $>0$ is much more stable. The NSE decreases rapidly after each peak caused by the snow-melt 


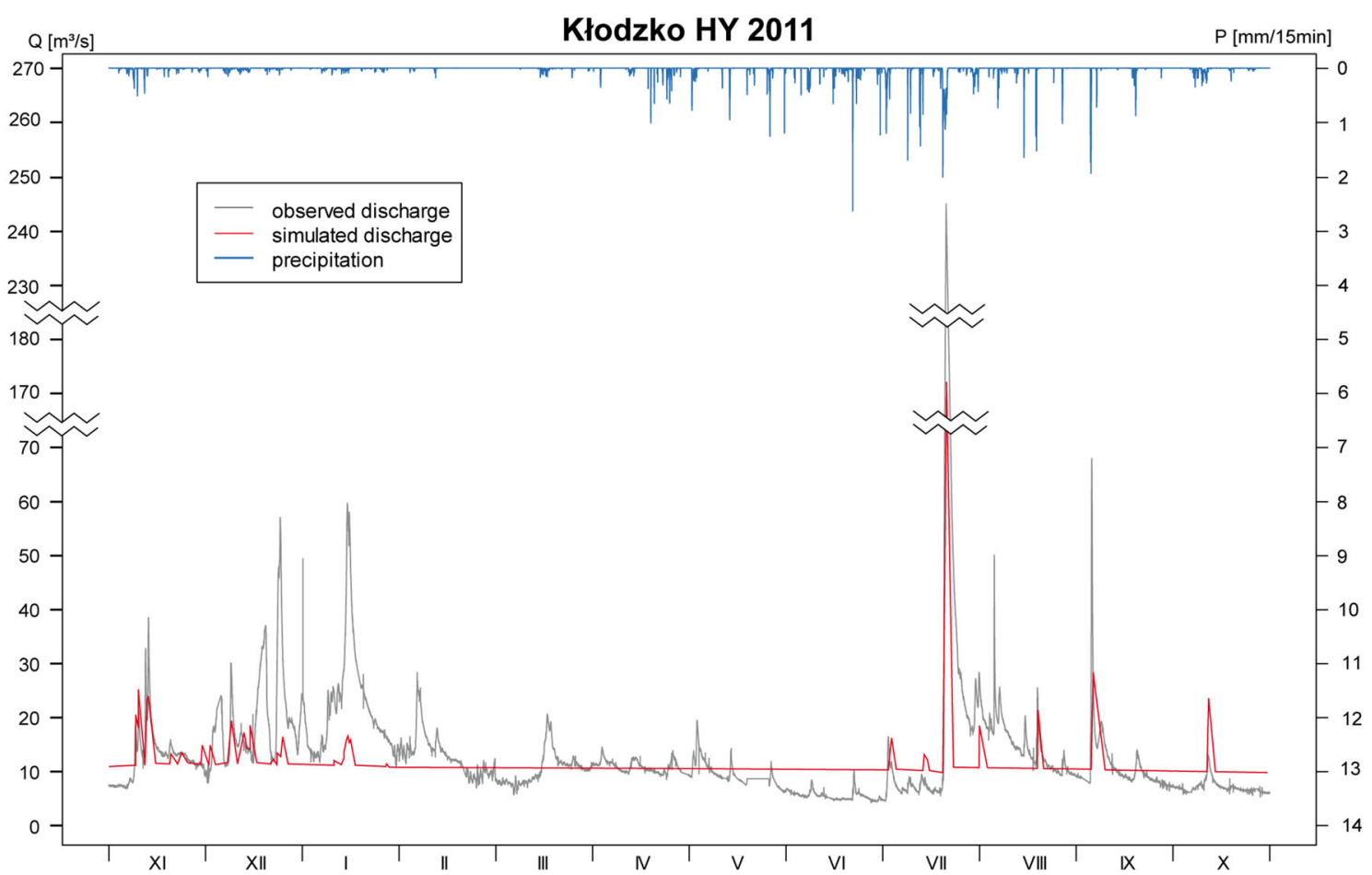

Fig. 5 TOPMODEL simulation results for the Kłodzko watershed in HY 2011

Table 6 Comparison of simulation results for chosen period lengths for Bystrzyca Kłodzka catchment in HY 2011

\begin{tabular}{|c|c|c|c|c|c|c|c|}
\hline Time span & 1 week & 2 weeks & 3 weeks & 1 month & 2 months & 3 months & 6 months \\
\hline Number of simulations & 359 & 352 & 345 & 336 & 306 & 276 & 246 \\
\hline Number of time steps in each simulation & 672 & 1344 & 2016 & 2880 & 5760 & 8640 & 11,520 \\
\hline Mean NSE & -0.52 & 0.09 & 0.22 & 0.28 & 0.34 & 0.39 & 0.41 \\
\hline Std dev. NSE & 2.22 & 5.25 & 0.53 & 0.48 & 0.43 & 0.44 & 0.44 \\
\hline Best NSE & 0.98 & 0.97 & 0.95 & 0.96 & 0.96 & 0.96 & 0.95 \\
\hline $\mathrm{NSE}>0.6(\%)$ & 25.07 & 26.42 & 25.79 & 26.78 & 30.06 & 32.97 & 42.27 \\
\hline $\mathrm{NSE}>0(\%)$ & 62.67 & 67.04 & 70.14 & 72.32 & 70.26 & 73.18 & 75.61 \\
\hline Mean RMSE & 1.69 & 2.00 & 2.18 & 2.34 & 2.74 & 2.90 & 2.92 \\
\hline
\end{tabular}

NSE Nash-Sutcliffe efficiency, RMSE root-mean-square error $\left(\mathrm{m}^{3} / \mathrm{s}\right)$

as indicated in Fig. 6. Another major dip corresponds to the storm from 24 July 2011, when the underestimation of the main peak flow affects the NSE value. The best performance of the model was noticed for the 6-month period. Just after the winter season, the NSE values rise gradually and reach a plateau of NSE $>0.9$ beginning with the simulations starting at the end of March. It has been noticed that for the longer time spans, the model was able to simulate the major peak from 24 July 2011 with higher accuracy.

Further analysis of the impact of the snow component was performed by limiting the modeling to period without snow cover: April to October for HY 2010, 2011, and
2012. Univariate analysis of the simulated discharge in comparison to the calculations for entire $\mathrm{HY}$ as well as NSE values confirms that the model performance is highly influenced by the snow-melt component (Table 7). For the best performing HY 2011, as predicted in optimal time span analysis, the NSE value was as high as 0.93 for the months without snow cover in comparison to 0.78 for entire year. The goodness-of-fit for simulations in HY 2010 and 2012 was also significantly enhanced by limiting modeling to the April-October period. NSE value for HY 2010 increased from 0.29 to 0.62 reaching the behavioral threshold; and in HY 2012, the value of NSE raised from 


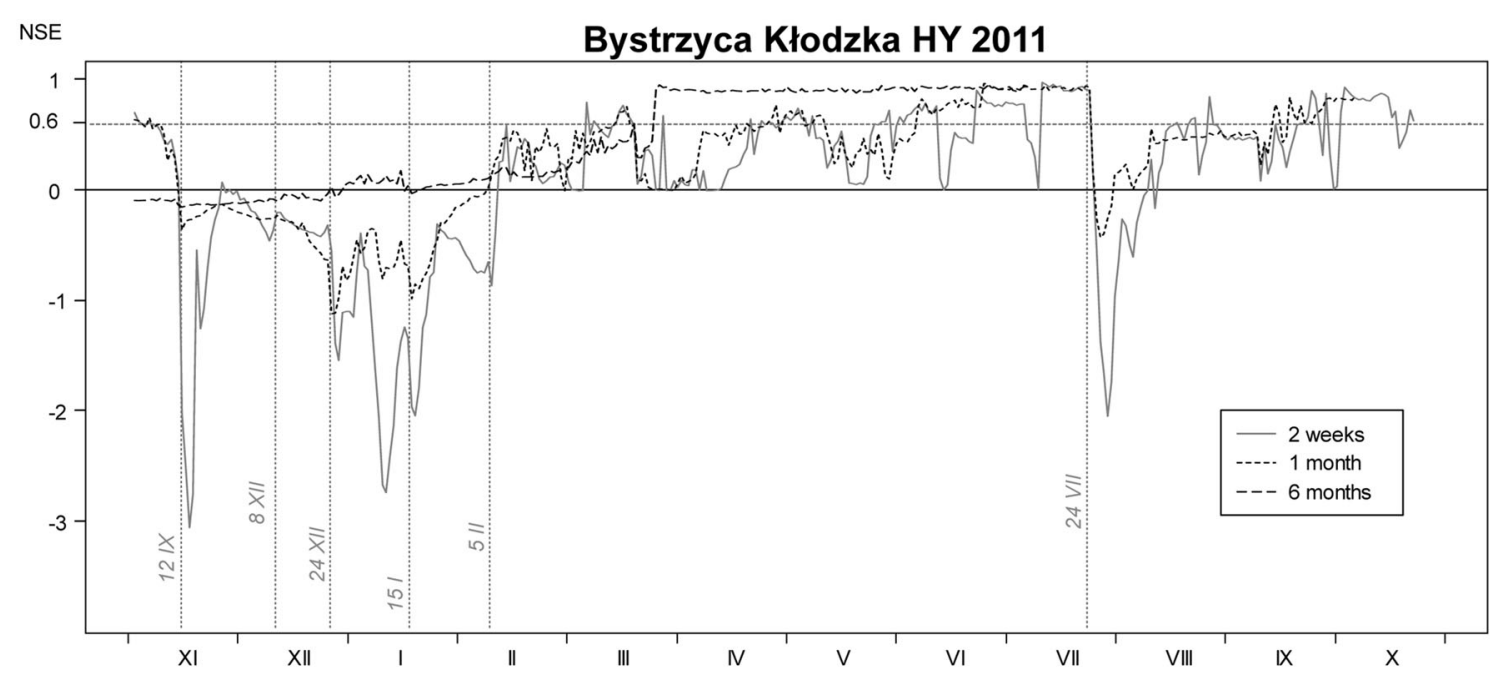

Fig. 6 Performance of TOPMODEL as a function of span of data used to calibrate the model

Table 7 Comparison of statistics for model performance in Bystrzyca catchment for entire HY and for months without snow cover (AprilOctober)

\begin{tabular}{llllllll}
\hline & HY & \multicolumn{5}{l}{ IV-X } \\
\cline { 2 - 4 } \cline { 7 - 9 } & 2010 & 2011 & 2012 & & 2010 & 2011 & 2012 \\
\hline NSE & 0.29 & 0.78 & 0.32 & & 0.62 & 0.93 & 0.57 \\
Standard dev. & 3.19 & 5.91 & 4.01 & 6.12 & 7.32 & 7.01 \\
\hline
\end{tabular}

0.32 to 0.57 . It should also be noted that for the experiment limited to the April-October period (Table 7).

Finally, it is worth noting that there were applications of TOPMODEL in temperate cold climate for which snow-melt component was not included (Lamb et al. 1997). This supports our approach and the comparison presented in Table 7.

\section{Model validation}

The optimized parameter set from HY 2011 in the best performing watershed Bystrzyca Kłodzka was applied to the same watershed for the HY 2009 to validate the model. In the validation exercise, the 6-month time span was used as it was shown to be the data length for which model skills were the superior over all the studied cases (Table 6). Thyssen polygons for spatial distribution of rainfall data were recalculated because of the lack of precipitation data in one of the station used for HY 2010-2012. Precipitation data from station located $8 \mathrm{~km}$ away were used as a substitute.

Validation performed for entire 2009 HY showed that the hydrograph fails to match with the observed one at the beginning of the year, during the snow-melting period. Following the procedure described in "Optimal time span for simulations", the simulations were limited to the shorter time spans, focusing on the period without snow cover and using the best performing parameter set calibrated for Bystrzyca catchment for the months without snow cover.

Model performed best for the summer and fall months, with the exception of the period from mid-June to midJuly, where the simulated hydrograph failed to match the observed one. Figure 7 shows the results of the validation preformed on the late summer months of the $2009 \mathrm{HY}$. The NSE value obtained for depicted time span was 0.73; and limiting the simulation period to only the months of August and September, the NSE value reaches 0.87 and predicts accurately the recession curve. Despite the high value of NSE and relatively accurate representation of the first peak, the hydrograph significantly underestimates the second peak in the period of simulation.

Validation showed satisfactory results also for the month of May 2009 (Fig. 8). The NSE of 0.63 is above the 0.6 threshold for being classified as behavioral. Similar to the above described period, the peaks of the hydrograph are underestimated and the model fails to predict accurately the last peak in the period showing only a slight rise in the discharge rates, when the observed values form the largest peak in this time span.

The poor performance of the model for the validation period of entire $2009 \mathrm{HY}$ as well as the months without snow cover can be explained by the uniqueness of conditions in the best performing $2011 \mathrm{HY}$, when the intense precipitation and very high discharge rates in the major peak from 24 July 2011 resulted in calibration of the parameters performing best in this unique conditions and failing to simulate the hydrograph in less extreme circumstances. Despite that, there were time spans in the validation period that the model demonstrated satisfactory results, only slightly lower than the values obtained during calibration period. 
Fig. 7 Validation of TOPMODEL for the Bystrzyca Kłodzka watershed
Fig. 8 Validation of TOPMODEL for the Bystrzyca Kłodzka watershed in the month of May 2009
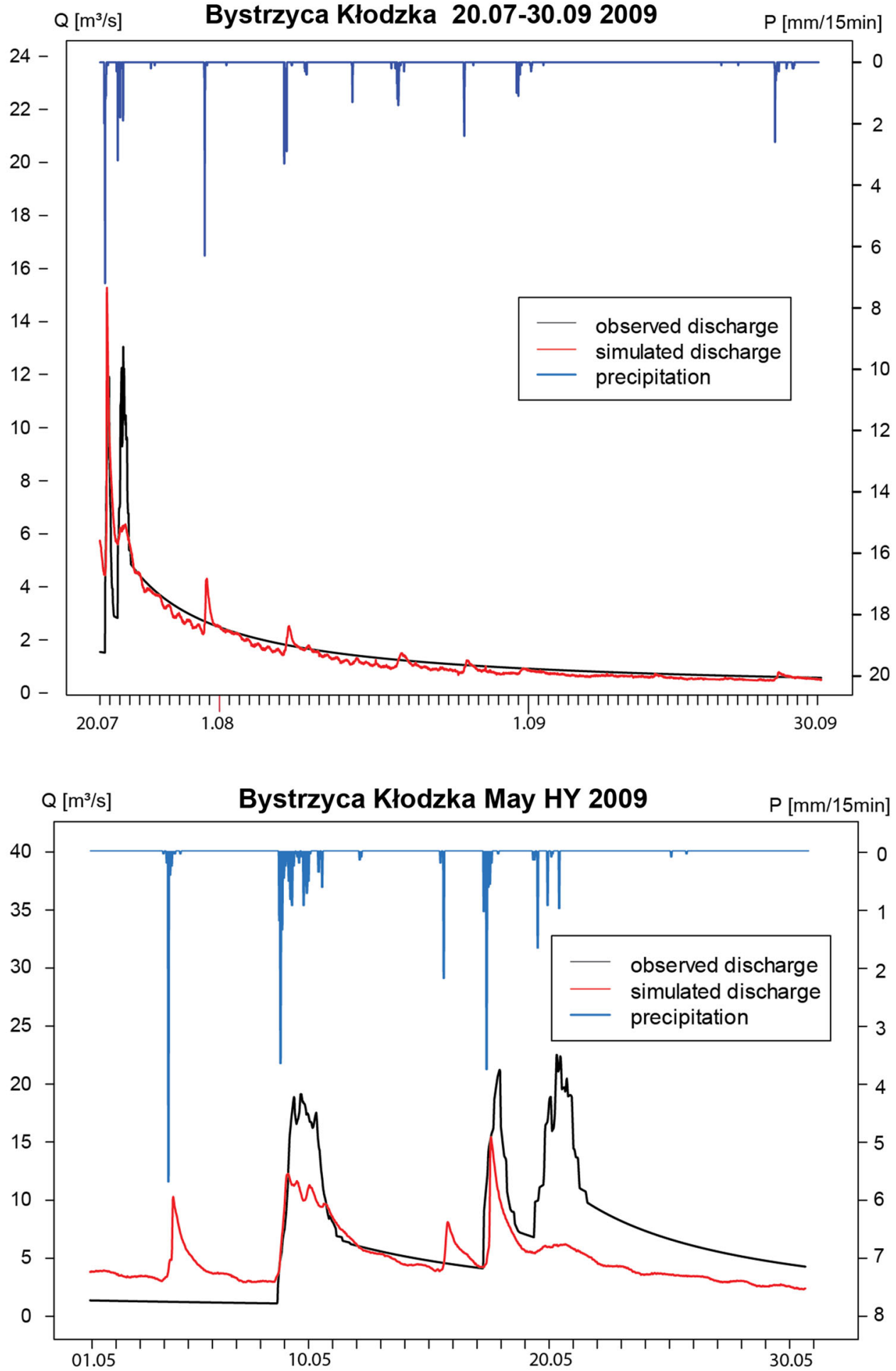

\section{Conclusions}

TOPMODEL was successfully applied to four subcatchments of the upper Nysa Kłodzka river basin, but was able to reproduce the main pattern of the hydrograph with acceptable accuracy only for two of them. The conclusions are the following.

1. Poor performance of the model in two catchments can have variety of reasons, including input data error, calibration inaccuracy, parameter uncertainty, and model structure. The most probable cause of 
misrepresentation of hydrograph lies in the snow-melt component that is not included in this basic version of TOPMODEL. A more sophisticated structure of the response function needs to be used to improve the TOPMODEL performance in all of the investigated watersheds. Low accuracy of the model can also be effect of the model inability to represent distributed rainfall pattern.

2. Complicated environment and lack of soil data make the calibration of parameters challenging. The Monte Carlo simulation produces the most suitable parameter sets, but they may not correspond to the actual conditions in the watershed.

3. It has been found that the goodness-of-fit increases along with time span of data used for TOPMODEL calibration, and among the studied periods, the halfyear solution produces the best agreement between data and model simulations. However, such estimates cannot be treated as global ones, since they are highly dependent on hydrological settings and weather conditions.

4. Simulations that do not include winter season provided promising results, the NSE for nearly half of the simulations using 6-month time span of data for Bystrzyca Kłodzka catchment are higher than 0.6.

5. Snow cover was found to impact the model performance, i.e., when the analysis is limited to snow-free months, the NSE values are considerably higher than for the entire year which includes periods of snow cover occurrence.

6. Validation performed using the best set of parameters obtained during calibration for the best performing watershed was found to demonstrate satisfactory results (obtained just slightly lower NSE values than during calibration period), but only for shorter time spans and failed to simulate the hydrograph for the entire HY used as validation period.

Acknowledgements The research has been financed by the National Science Centre (Poland), research Project no. 2011/01/D/ST10/04171 under leadership of Dr. hab. Tomasz Niedzielski, Professor at the University of Wrocław (Poland). The authors thank the authorities of the County Office in Kłodzko for productive partnership and providing us with the data of the Local Flood Monitoring System (Lokalny System Osłony Przeciwpowodziowej-LSOP). The tabulated rating curves have been acquired from the Institute of Meteorology and Water Management, National Research Institute (Poland). Sincere gratitude needs to be expressed to Prof. Renata Romanowicz for the guidance and support in clarifying the model concepts and nuances. Further thanks go to Prof. Helena Mitasova who provided comments and valuable suggestions during the last stage of project. We also thank Dr. Wouter Buytaert for unveiling the details of the source code. The daily evapotranspiration data for Goerlitz were obtained courtesy of the KLAPS/NEYMO projects, and we wish to thank Mr. Andreas Völlings, Sächsisches Landesamt für Umwelt, Landwirtschaft und Geologie (Germany), for his approval for use of the aforementioned data set. We are also grateful to Mrs. Magdalena Stec for preparing evapotranspiration time series. We are also indebted to Dr. Danuta Trojan for discussions on LSOP and on water management problems in Kłodzko County. We thank Dr. hab. Mariusz Szymanowski, Dr. Małgorzata Wieczorek, and Dr. Waldemar Spallek for preparing the Digital Elevation Model that has been used in this study. Last but not least, we express our thanks to Mr. Bartłomiej Miziński who kindly helped to verify the rating curve models.

\section{Compliance with ethical standards}

Conflict of interest On behalf of all authors, the corresponding author states that there is no conflict of interest.

Open Access This article is distributed under the terms of the Creative Commons Attribution 4.0 International License (http://creative commons.org/licenses/by/4.0/), which permits unrestricted use, distribution, and reproduction in any medium, provided you give appropriate credit to the original author(s) and the source, provide a link to the Creative Commons license, and indicate if changes were made.

\section{References}

Bárdossy A (2007) Calibration of hydrological model parameters for ungauged catchments. Hydrol Earth Syst Sci 11(2):703-710

Barling RD, Moore ID, Grayson RB (1994) A quasi-dynamic wetness index for characterizing the spatial distribution of zones of surface saturation and soil water content. Water Resour Res 30(4):1029-1044

Bastola S, Ishidaira H, Takeuchi K (2008) Regionalisation of hydrological model parameters under parameter uncertainty: a case study involving TOPMODEL and basins across the globe. J Hydrol 357:188-206

Bednorz E (2011) Synoptic conditions of the occurrence of snow cover in central European lowlands. Int $\mathrm{J}$ Climatol 13(8):1108-1118

Beven K (1986) Runoff production and flood frequency in catchments of order n: an alternative approach. In: Gupta VK, RodríguezIturbe I, Wood EF (eds) Scale problems in hydrology. Reider, Dordrecht, pp 107-131

Beven K (1997) TOPMODEL: a critique. Hydrol Process 11(9):1069-1085

Beven K, Binley A (1992) The future of distributed models: model calibration and uncertainty prediction. Hydrol Process 6(3):279-298

Beven K, Freer J (2001a) A dynamic topmodel. Hydrol Process 15(10): 1993-2011

Beven K, Freer J (2001b) Equifinality, data assimilation, and uncertainty estimation in mechanistic modelling of complex environmental systems using the GLUE methodology. J Hydrol 249:11-29

Beven KJ, Kirkby MJ (1979) A physically based, variable contributing area model of basin hydrology. Hydrol Sci 24:43-69

Beven K, Wood EF (1983) Catchment geomorphology and the dynamics of runoff contributing areas. J Hydrol 65:139-158

Beven KJ, Kirkby MJ, Schofield N, Tagg AF (1984) Testing a physically-based flood forecasting model (TOPMODEL) for three U.K. catchments. J Hydrol 69:119-143

Beven KJ, Quinn PF, Lamb R, Romanowicz R, Freer J (1995) TOPMODEL. In: Singh VP (ed) Computer models of watershed 
hydrology. Water Resources Publications, Highlands Ranch, pp 627-668

Blazkova S, Beven K (1997) Flood frequency prediction for data limited catchments in the Czech Republic using a stochastic rainfall model and TOPMODEL. J Hydrol 195:256-278

Blazkova S, Beven KJ, Kulasova A (2002) On constraining TOPMODEL hydrograph simulations using partial saturated area information. Hydrol Process 16(2):441-458

Brasington J, Richards K (1998) Interactions between model predictions, parameters and DTM scales for TOPMODEL. Comput Geosci 24:299-314

Cameron DS, Beven KJ, Tawn J, Blazkova S, Naden P (1999) Flood frequency estimation by continuous simulation for a gauged upland catchment (with uncertainty). J Hydrol 219:169-187

Chairat S, Delleur JW (1993) Effects of the topographic index distribution on predicted runoff using grass. J Am Water Resour Assoc 29:1029-1034

Chen J, Wu Y (2012) Advancing representation of hydrologic processes in the soil and water assessment tool (SWAT) through integration of the TOPographic MODEL (TOPMODEL) features. J Hydrol 420-421:319-328

Choi HT, Beven K (2007) Multi-period and multi-criteria model conditioning to reduce prediction uncertainty in an application of TOPMODEL within the GLUE framework. J Hydrol 332:316-336

Criss RE, Winston WE (2008) Do nash values have value? Discussion and alternate proposals. Hydrol Processes 22(14):2723-2725

Desmet PJJ, Govers G (1996) A GIS procedure for automatically calculating the USLE LS factor on topographically complex landscape units. J Soil Water Conserv 51:427-433

Drabiński A, Radczuk L, Nyc K, Mokwa M, Olearczyk D, Markowska J, Bac-Bronowicz J, Chmielewska I, Jawecki B, Gromada O, Pikul K, Malczewska B, Goździk M (2006) Program Małej Retencji Wodnej w województwie dolnośląskim. Sejmik Województwa Dolnośląskiego, Wrocław

Drzewiecki W, Wężyk P, Pierzchalski M, Szafrańska B (2014) Quantitative and qualitative assessment of soil erosion risk in Małopolska (Poland), supported by an object-based analysis of high-resolution satellite images. Pure Appl Geophys 171(2014):867-895

Durand P, Robson A, Neal C (1992) Modelling the hydrology of submediterranean montane catchments (Mont-Lozère, France) using TOPMODEL: initial results. J Hydrol 139:1-14

Erskine RH, Green TR, Ramirez JA, MacDonald LH (2006) Comparison of grid-based algorithms for computing upslope contributing area. Water Resour Res 42:1-9

Fisher JI, Beven KJ (1996) Modelling of streamflow at Slapton Wood using TOPMODEL within an uncertainty estimation framework. Field Stud 8:577-584

Franchini M, Wendling J, Obled C, Todini E (1996) Physical interpretation and sensitivity analysis of the TOPMODEL. J Hydrol 175:293-338

Freer J, Beven K, Ambroise B (1996) Bayesian estimation of uncertainty in runoff prediction and the value of data: an application of the GLUE approach. Water Resour Res 32(7):2161-2173

Freer J, Beven K, Peters N (2003) Multivariate seasonal period model rejection within the generalised likelihood uncertainty estimation procedure. In: Duan Q, Gupta H, Sorooshian S, Rousseau AN, Turcotte R (eds) Calibration of watershed models. AGU Books, Washington, pp 69-87

Furusho C, Andrieu H, Chancibault K (2014) Analysis of the hydrological behaviour of an urbanizing basin. Hydrol Process 28(4):1809-1819

Gallart F, Latron J, Llorens P, Beven KJ (2008) Upscaling discrete internal observations for obtaining catchment-averaged
TOPMODEL parameters in a small Mediterranean mountain basin. Phys Chem Earth 33:1090-1094

Geographic Characteristic of Counties (2004) IUNG-Institute of Soil Science and Plant Cultivation, Puławy, Poland

Godek M, Sobik M, Błaś M, Polkowska Ż, Owczarek P, Bokwa A (2015) Tree rings as an indicator of atmospheric pollutant deposition to subalpine spruce forests in the Sudetes (Southern Poland). Atmos Res 151:259-268

Gumindoga W (2010) Hydrologic impacts of landuse change in the Upper Gilgel Abay River Basin, Ethiopia: TOPMODEL Application., Ph.D. Thesis, University of Twente, Faculty of GeoInformation and Earth Observation (ITC), Enschede, Netherlands

Hewlett JD, Hibbert AR (1967) Factors affecting the response of small watersheds to precipitation in humid areas. Forest hydrology. Pergamon Press, New York, pp 275-290

Holko L, Lepistö A (1997) Modelling the hydrological behaviour of a mountain catchment using TOPMODEL. J Hydrol 196:361-377

Holländer HM, Blume T, Bormann H, Buytaert W, Chirico GB, Exbrayat J-F, Gustafsson D, Hölzel H, Kraft P, Stamm C, Stoll S, Blöschl G, Flühler H (2009) Comparative predictions of discharge from an artificial catchment (Chicken Creek) using sparse data. Hydrol Earth Syst Sci 13:2069-2094

Hornberger GM, Beven KJ, Cosby BJ, Sappington DE (1985) Shenandoah watershed study: calibration of a topography-based, variable contributing area hydrological model to a small forested catchment. Water Resour Res 21(12):1841-1850

Krause P, Boyle DP, Bäse F (2005) Comparison of different efficiency criteria for hydrological model assessment. Adv Geosci 5:89-97

Kuczera G, Mroczkowski M (1998) Assessment of hydrologic parameter uncertainty and the worth of multiresponse data. Water Resour Res 34(4):751-763

Lamb R, Beven KJ, Myrabø S (1997) Discharge and water table predictions using a generalized TOPMODEL formulation source. Hydrol Process 11(9):1145-1167

Latocha A, Migoń P (2006) Geomorphology of medium-high mountains under changing human impact, from managed slopes to nature restoration: a study from the Sudetes, SW Poland. Earth Surf Proc Land 31(13):1657-1673

Liu S, Graham WD, Jacobs JM (2005) Daily potential evapotranspiration and diurnal climate forcings: influence on the numerical modelling of soil water dynamics and evapotranspiration. J Hydrol 309:39-52

Merot P, Ezzahar B, Walter C, Aurousseau P (1995) Mapping waterlogging of soils using digital terrain models. Hydrol Process 9(1):27-34

Migoń P, Placek A (2014) Litologiczno-strukturalne uwarunkowania rzeźby Sudetów (Lithological and structural control on the relief of the Sudetes). Przegląd Geologiczny 62(1):36-43

Migoń P, Wyjątkowe zdarzenia przyrodnicze na Dolnym Śląsku i ich skutki (2010) In: Rozprawy Naukowe Instytutu Geografii i Rozwoju Regionalnego Uniwersytetu Wrocławskiego, Uniwersytet Wrocławski, Wrocław, Poland, pp 35-80

Mitasova H, Hofierka J, Zlocha M, Iverson LR (1996) Modeling topographic potential for erosion and deposition using GIS. Int J Geogr Inf Syst 10:629-641

Molicova H, Grimaldi M, Bonell M, Hubert P (1997) Using TOPMODEL towards identifying and modelling the hydrological patterns within a headwater, humid, tropical catchment. Hydrol Process 11(9):1169-1196

Moore ID, Burch GJ (1986) Physical basis of the length-slope factor in the universal soil loss equation. Soil Sci Soc Am J 50:1294-1298

Moore RD, Thompson JC (1996) Are water table variations in a shallow forest soil consistent with the TOPMODEL concept? Water Resour Res 32:663-669 
Moore ID, Wilson JP (1992) Length-slope factors for the revised universal soil loss equation: simplified method of estimation. J Soil Water Conserv 47:423-428

Moriasi DN, Arnold JG, Van Liew MW, Bingner RL, Harmel RD, Veith TL (2007) Model evaluation guidelines for systematic quantification of accuracy in watershed simulations. Trans ASABE 50(3):885-900

Nash JE, Sutcliffe JV (1970) River flow forecasting through conceptual models part I-a discussion of principles. J Hydrol 10:282-290

Niedzielski T, Miziński B (2017) Real-time hydrograph modelling in the upper Nysa Kłodzka river basin (SW Poland): a two-model hydrologic ensemble prediction approach. Stoch Env Res Risk Assess 31:1555-1576

Niedzielski T, Miziński B, Kryza M, Netzel P, Wieczorek M, Kasprzak M, Kosek W, Migoń P, Szymanowski M, Jeziorska J, Witek M (2014) HydroProg: a system for hydrologic forecasting in real time based on the multimodelling approach. Meteorol Hydrol Water Manag Res Oper Appl 2:65-72

Nourani V, Mano A (2007) Semi-distributed flood runoff model at the subcontinental scale for southwestern Iran. Hydrol Process 21(23):3173-3180

Nourani V, Zanardo S (2014) Wavelets-based regularization of the extracted topographic index from high-resolution topography for hydro-geomorphic applications. Hydrol Process 28:1345-1357

Nourani V, Roughani A, Gebremichael M (2011) Topmodel capability for rainfall-runoff modeling of the Ammameh watershed at different time scales using different terrain algorithms. J Urban Environ Eng 5:1-14

Orczykowski T, Tiukało A (2016) Retention of afforestation areas as part of flood protection-research site and methodology for headwater watershad in Poland/Retencja Leśna Zlewni Jako Element Ochrony Przeciwpowodziowej. Civ Environ Eng Rep 20:59-70

Pawlik Ł, Migoń P, Owczarek P, Kacprzak A (2013) Surface processes and interactions with forest vegetation on a steep mudstone slope, Stołowe Mountains, SW Poland. CATENA 109:203-216

Peters NE, Freer J, Beven K (2003) Modelling hydrologic responses in a small forested catchment (Panola Mountain, Georgia, USA): a comparison of the original and a new dynamic TOPMODEL. Hydrol Process 179(2):345-362

Piasecki J (1996) Wybrane cechy klimatu Masywu Śnieżnika. In: Jahn A, Kozłowski S, Pulina M (eds) Masyw Śnieżnika-zmiany w środowisku przyrodniczym. PAE, Warszawa, pp 189-218

Piñol J, Beven K, Freer J (1997) Modelling the hydrological response of mediterranean catchments, Prades, Catalonia. The use of distributed models as aids to hypothesis formulation. Hydrol Process 11(9):1287-1306
Quinn PF, Beven KJ (1993) Spatial and temporal predictions of soil moisture dynamics, runoff, variable source areas and evapotranspiration for plynlimon, mid-wales. Hydrol Process 7(4):425-448

Robson A, Beven K, Neal C (1992) Towards identifying sources of subsurface flow: a comparison of components identified by a physically based runoff model and those determined by chemical mixing techniques. Hydrol Process 6(2):199-214

Romanowicz RJ (2007) Data based mechanistic model for low flows: implications for the effects of climate change. J Hydrol 336:74-83

Romanowicz R, Beven K (2003) Estimation of flood inundation probabilities as conditioned on event inundation maps. Water Resour Res 39(3):1073-1085

Schmuck A (1969) Meteorologia i klimatologia dla WSR. PWN, Warszawa

Shrestha S, Bastola S, Babel MS, Dulal KN, Magome J, Hapuarachchi HAP, Takeuchi K (2007) The assessment of spatial and temporal transferability of a physically based distributed hydrological model parameters in different physiographic regions of Nepal. J Hydrol 347:153-172

Sigdel A, Jha R, Bhatta D, Abou-Shanab RAI, Sapireddy VR, Jeon B-H (2011) Applicability of TOPMODEL in the catchments of Nepal: Bagmati River Basin. Geosyst Eng 14(4):181-190

Sun S, Deng H (2004) A study of rainfall-runoff response in a catchment using TOPMODEL. Adv Atmos Sci 21(1):87-95

Szalińska W, Tokarczyk T, Jełowicki J, Chorążyczewski A, Michalski A, Tiukało A, Ostojski M (2014) Środowisko obliczeniowe operacyjnego modelu typu opad-odpływ. Monografie Komitetu Gospodarki Wodnej PAN XX, pp 293-306

Taschner S (2003) Flood modelling in the Ammer watershed using coupled meteorological and hydrological models, Ph.D. Thesis, Ludwig-Maximilians-Universität München, Germany

Waroszewski J, Kalinski K, Malkiewicz M, Mazurek R, Kozlowski G, Kabala C (2013) Pleistocene-holocene cover-beds on granite regolith as parent material for Podzols - an example from the Sudeten Mountains. CATENA 104:161-173

Wieczorek M, Migoń P (2014) Automatic relief classification versus expert and field based landform classification for the mediumaltitude mountain range, the Sudetes, SW Poland. Geomorphology 206:133-146

Wolock DM, Hornberger GM, Musgrove TJ (1990) Topographic effects on flow path and surface water chemistry of the Llyn Brianne catchments in Wales. J Hydrol 115(1-4):243-259

Wood EF, Sivapalan M, Beven K, Band L (1988) Effects of spatial variability and scale with implications to hydrologic modeling. J Hydrol 102:27-47 